\title{
Macrophage Inflammatory Protein-1 $\alpha$ A Novel Chemotactic Cytokine for Macrophages in Rheumatoid Arthritis
}

\author{
Alisa E. Koch, ${ }^{\star 5 ! \mid}$ Steven L. Kunkel, ${ }^{\star 1}$ Lisa A. Harlow, ${ }^{\star 5}$ Daphne D. Mazarakis, ${ }^{\star \star 5}$ G. Kenneth Haines, ${ }^{\star 5}$ Marie D. Burdick, ${ }^{\star 1}$ \\ Richard M. Pope, *\$" and Robert M. Strieter * \\ Departments of ${ }^{*}$ Medicine and ${ }^{\ddagger}$ Pathology, ${ }^{\S}$ Northwestern University Medical School, and "Veteran's Administration Lakeside Medical \\ Center, Chicago, Illinois 60611; and 'The University of Michigan Medical Center, Ann Arbor, Michigan 48109
}

\begin{abstract}
We have shown that human macrophages $(m \phi s)$ play an important role in the elaboration of chemotactic cytokines in rheumatoid arthritis (RA) (Koch, A. E., S. L. Kunkel, J. C. Burrows, H. L. Evanoff, G. K. Haines, R. M. Pope, and R. M. Strieter. 1991. J. Immunol. 147:2187; Koch, A. E., S. L. Kunkel, L. A. Harlow, B. Johnson, H. L. Evanoff, G. K. Haines, M. D. Burdick, R. M. Pope, and R. M. Strieter. 1992. J. Clin. Invest. 90:772; Koch, A. E., P. J. Polverini, S. L. Kunkel, L. A. Harlow, L. A. DiPietro, V. M. Elner, S. G. Elner, and R. M. Strieter. 1992. Science (Wash. DC). 258:1798). Recently, m $\phi$ inflammatory protein-1 (MIP-1 $\alpha$ ), a cytokine with chemotactic activity for $m \phi s$ and neutrophils (PMNs), has been described. We have examined the production of MIP-1 $\alpha$ using sera, synovial fluid (SF), and synovial tissue (ST) from 63 arthritic patients. MIP-1 $\alpha$ was higher in RA SF (mean, $29 \pm 8$ $\mathrm{ng} / \mathrm{ml}[\mathrm{SE}])$ compared with other forms of arthritis (2.8 \pm 1.7$)$, or osteoarthritis $(0.7 \pm 0.4 ; P<0.05)$. RA SF MIP-1 $\alpha$ was greater than that found in either RA or normal peripheral blood (PB) $(P<0.05)$. Anti-MIP-1 $\alpha$ neutralized $36 \pm 3 \%$ (mean $\pm \mathrm{SE}$ ) of the chemotactic activity for $m \phi s$, but not PMNs, found in RA SFs. RA SF and PB mononuclear cells produced antigenic MIP-1 $\alpha$. Mononuclear cell MIP-1 $\alpha$ production was augmented with phytohemagglutinin or LPS. Isolated RA ST fibroblast production of antigenic MIP-1 $\alpha$ was augmented upon incubation of cells with LPS, and to a lesser extent with tumor necrosis factor- $\alpha$. Isolated RA ST $\mathbf{m} \phi \mathbf{s}$ expressed constitutive MIP-1 $\alpha$ mRNA and antigenic MIP-1 $\alpha$. Using ST immunohistochemistry, MIP-1 $\alpha^{+}$cells from RA compared with normal were predominantly $m \phi s$ and lining cells $(P<0.05)$. These results suggest that MIP-1 $\alpha$ plays a role in the selective recruitment of $\mathbf{m} \phi \mathbf{s}$ in synovial inflammation associated with RA. (J. Clin. Invest. 1994. 93:921-928.) Key words: macrophage • synovium • synovial fluid • inflammation • chemotaxis
\end{abstract}

\section{Introduction}

Rheumatoid arthritis (RA) ${ }^{1}$ is characterized by persistent synovial inflammation, destruction of bone and cartilage, and nu-

Address correspondence to Dr. Alisa E. Koch, Department of Medicine, Northwestern University Medical School, Ward Building, 3-315, 303 East Chicago Avenue, Chicago, IL 60611.

Received for publication 16 February 1993 and in revised form 20 August 1993.

1. Abbreviations used in this paper: MCP-1, monocyte chemoattractant protein-1; $m \phi$, macrophage; OA, osteoarthritis; PB, peripheral blood; RA, rheumatoid arthritis; rh, recombinant human; SF, synovial fluid; ST, synovial tissue.

The Journal of Clinical Investigation, Inc.

Volume 93, March 1994, 921-928 merous systemic manifestations (1). Chronic inflammatory cells, including macrophages $(\mathrm{m} \phi \mathrm{s})$ and lymphocytes, are present in the synovial tissues (STs) (1). Cytokines are produced by cells within the inflamed STs, perhaps accounting for a number of the pathological and clinical manifestations of RA (2). These cytokines are predominantly products of synovial $\mathrm{m} \phi \mathrm{s}$ and fibroblasts, including IL- $1,-6$, and -8 , TNF- $\alpha$, colony stimulating factor-1 (CSF-1), GM-CSF, IL-1 receptor antagonist protein, monocyte chemoattractant protein-1 (MCP-1), and leukemia inhibitory factor (3-18). These cytokines alone or in concert serve to orchestrate the destructive phase of RA synovitis.

Recently, a novel chemotactic cytokine, MIP- $1 \alpha$, has been described (19-23). MIP- $1 \alpha$ is an $8-\mathrm{kD}$ protein produced by LPS-activated $\mathrm{m} \phi \mathrm{s}$, other hematopoietic cells such as B and T lymphocytes, PMNs, as well as fibroblasts under some conditions $(19,24)$. MIP-1 $\alpha$, a member of the chemokine gene superfamily, is chemokinetic for PMNs as well as chemotactic for $\mathrm{m} \phi \mathrm{s}$ and $\mathrm{T}$ cells, and hence may play a role in the recruitment of inflammatory leukocytes into the inflamed joint $(19,25$, 26 ). The role of this cytokine in RA has not, as yet, been defined.

In this study, we found significantly greater levels of MIP$1 \alpha$ in synovial fluids (SFs) from patients with RA as compared with osteoarthritis (OA) or other inflammatory and noninflammatory arthritis. MIP- $1 \alpha$ levels found in RA SFs were significantly greater than the quantities found in normal or RA peripheral blood (PB). RA SF chemotactic activity for normal PB $\mathrm{m} \phi \mathrm{s}$, but not PMNs, was inhibited $36 \pm 3 \%$ (mean $\pm \mathrm{SE}$ ) upon incubation with anti-MIP-1 $\alpha$. A variety of cells, including ST fibroblasts and $\mathrm{m} \phi \mathrm{s}$, as well as SF mononuclear cells, produced MIP- $1 \alpha$. RA ST $\mathrm{m} \phi$ s constitutively produced both MIP- $1 \alpha$ mRNA and protein. In arthritic as well as normal STs, we identified the predominant MIP $-1 \alpha^{+}$cells as the synovial lining cells and subsynovial $\mathrm{m} \phi \mathrm{s}$. The numbers of MIP- $1 \alpha^{+}$ cells found in the RA synovium were significantly greater than those found in the ST of normal individuals.

\section{Methods}

Reagent preparation. Human recombinant IL- $1 \beta$ with a specific activity of $5 \times 10^{8} \mathrm{U} / \mathrm{mg}$ was purchased from R \& D Systems (Minneapolis, MN). Human recombinant TNF- $\alpha$ with a specific activity of $1.3 \times 10^{7}$ $\mathrm{U} / \mathrm{mg}$ was a gift from Upjohn Co. (Kalamazoo, MI). Human recombinant MIP-1 $\alpha$ was purchased from R \& D Systems. LPS (Escherichia coli, 0111;B4) was obtained from Sigma Chemical Co. (St. Louis, MO). PHA was obtained from Burrows Wellcome (Research Triangle Park, NC). Polyclonal antihuman MIP- $1 \alpha$ was produced by immunization of rabbits with recombinant MIP- $1 \alpha$ with CFA. This antibody does not cross-react with the following cytokines: TNF- $\alpha$, IL-1, IL-2, IL-4, IL-6, or IFN- $\gamma$. In addition, the antibody does not cross-react with members of the C-C chemokine family, including MCP-1, RANTES, and macrophage inflammatory protein $1 \beta$ (MIP- $1 \beta)$, or 
members of the C-X-C chemokine family, including GRO- $\alpha$, epithelial neutrophil-activating peptide-78, neutrophil-activating peptide-2, and IP-10 (24, 27, 28). mAb Leu-M5 (anti-CD1 1c, p150,95, CR4 receptor) detects $m \phi s$ (Becton Dickinson \& Co., Mountain View, CA). $\mathrm{mAb}$ FVIII detects factor VIII-related antigen present on endothelial cells (Dakopatts, Carpinteria, CA).

Patient population. SFs were isolated from patients with either RA, $\mathrm{OA}$, or other forms of arthritis during therapeutic arthrocentesis. PB specimens were obtained from some of the RA patients as well as from healthy volunteers. SFs and PB were used for isolation of mononuclear cells. ST was obtained from patients undergoing total joint replacements who met the American College of Rheumatology criteria for RA or OA $(29,30)$. Normal STs were obtained from fresh autopsies. STs from these patients were snap frozen in OCT (Miles Laboratories, Elkhart, IN). Alternatively, fresh RA tissues were used for isolation of $m \phi s$ or fibroblasts (see below). All specimens were obtained with Institutional Review Board approval.

Isolation of human RA SF and blood mononuclear cells and PMNs. Mononuclear cells from heparinized RA SFs were isolated by gradient centrifugation using Histopaque-1077 (Sigma Diagnostics, St. Louis, MO), as previously described (31). Mononuclear cells were isolated from the PB of normal volunteers, using Sepracell-MN (Sepratech Corp., Oklahoma City, OK), as described. PMNs were isolated using Ficoll-Hypaque density centrifugation (Accurate Chem. \& Sci. Corp., Westbury, NY). Mononuclear cells or isolated lymphocytes or $\mathrm{m} \phi \mathrm{s}$ (2 $\times 10^{6}$ cells $\left./ \mathrm{ml}\right)$ were incubated with or without PHA $(1 \mu \mathrm{g} / \mathrm{ml})$ or LPS $(5 \mu \mathrm{g} / \mathrm{ml})$ and cultured in 24-well plates for $90 \mathrm{~h}$ at $37^{\circ} \mathrm{C}$ in RPMI $+10 \%$ FCS.

Isolation of human RA ST fibroblasts and $m \phi s$ and preparation of conditioned media. Fresh STs were minced and digested in a solution of dispase, collagenase, and DNase, as previously described $(32,33)$. Synovial fibroblast cells were cultured in RPMI + 10\% FCS + gentamicin in 75-mm tissue culture flasks (Costar, Cambridge, MA). Upon reaching confluence, the cells were passaged by brief trypsinization (32). The cells were used at passage 4 or older, at which time they were a homogenous population of fibroblasts. The cells were plated at a concentration of 3.1-4 × $10^{5}$ cells/well in 24-well plates (Costar) in 1 $\mathrm{ml}$ serum-free RPMI. Various concentrations of IL- $1 \beta$, TNF- $\alpha$, or LPS in RPMI were added, and conditioned media harvested after $24 \mathrm{~h}$.

For isolation of $m \phi s$, the STs were minced and digested as described above. The resultant single-cell suspensions were fractionated into density-defined subpopulations by isopyknic centrifugation through continuous preformed Percoll gradients ( Pharmacia Fine Chemicals, Piscataway, $\mathrm{NJ}$ ). $\mathrm{m} \phi \mathrm{s}$ were enriched by adherence to fibronectin-coated collagen gels and selective trypsinization (incubation with trypsin/ EDTA for 5-10 $\mathrm{min})(32,33) . \mathrm{m} \phi \mathrm{s}$ were harvested from the collagen gels by treatment with clostridial collagenase and found to be $\geq 90 \%$ pure, as assessed by $F_{c}$ receptor-mediated phagocytosis of IgG opsonized sheep red blood cells, esterase staining, and staining with commercial anti-m $\phi$ mAbs $(32,33)$.

$M I P-1 \alpha$ ELISA. Antigenic MIP-1 $\alpha$ was measured using a modification of a double ligand method as described $(24,27,28)$. In brief, 96-well plates (Nunc, Kamstrup, Denmark) were coated with $50 \mu \mathrm{l} /$ well rabbit anti-MIP- $1 \alpha\left(3.2 \mu \mathrm{g} / \mathrm{ml}\right.$ in $0.6 \mathrm{M} \mathrm{NaCl}, 0.26 \mathrm{M} \mathrm{H}_{3} \mathrm{BO}_{4}$, and $0.08 \mathrm{~N} \mathrm{NaOH}, \mathrm{pH} \mathrm{9.6)}$ for $16 \mathrm{~h}$ at $4^{\circ} \mathrm{C}$ and then washed in PBS, pH $7.5,0.05 \%$ Tween-20 (wash buffer). Nonspecific binding sites were blocked with $2 \%$ BSA in PBS $(200 \mu 1)$, and the plates incubated for 90 min at $37^{\circ} \mathrm{C}$. Plates were rinsed three times with wash buffer, and diluted (neat, 1:5, and 1:10) test sample $(50 \mu \mathrm{l})$ in duplicate was added, followed by incubation for $1 \mathrm{~h}$ at $37^{\circ} \mathrm{C}$. Plates were washed four times, and $50 \mu \mathrm{l} /$ well biotinylated rabbit anti-MIP- $1 \alpha(6 \mu \mathrm{g} / \mathrm{ml}$ in PBS, $\mathrm{pH}$ $7.5,0.05 \%$ Tween-20, 2\% FCS) was added for $45 \mathrm{~min}$ at $37^{\circ} \mathrm{C}$. Plates were washed four times, streptavidin-peroxidase conjugate $(100 \mu \mathrm{g} /$ $\mathrm{ml}$ ) (Dakopatts, Carpinteria, CA) was added, and the plates were incubated for $30 \mathrm{~min}$ at $37^{\circ} \mathrm{C}$. The plates were washed three times, and 100 $\mu \mathrm{l}$ chromogen substrate $(0.67 \mathrm{mg} / \mathrm{ml}$ orthophenylenediamine dichloride) (Dakopatts) was added. The plates were incubated at $25^{\circ} \mathrm{C}$ for 6 min, and the reaction was terminated with $50 \mu \mathrm{l} /$ well of $3 \mathrm{M} \mathrm{H}_{2} \mathrm{SO}_{4}$ solution in wash buffer plus $2 \%$ FCS. Plates were read at $490 \mathrm{~nm}$ in an ELISA reader. Standards were $1 / 2 \log$ dilutions of recombinant MIP- $1 \alpha$ from $100 \mathrm{ng} / \mathrm{ml}$ to $1 \mathrm{pg} / \mathrm{ml}(50 \mu \mathrm{l} /$ well $)$. The ELISA consistently detected MIP- $1 \alpha$ concentrations $>50 \mathrm{pg} / \mathrm{ml}$.

Northern blot analysis. Total cellular RNA was obtained from 2.5 $\times 10^{6} \mathrm{RA}$ ST $\mathrm{m} \phi \mathrm{s}$ using a modification of our previously described method $(3,16)$. Briefly, cells were scraped into a solution containing $25 \mathrm{mM}$ Tris, $\mathrm{pH} 8.0,4.2 \mathrm{M}$ guanidine isothiocyanate, $0.5 \%$ Sarkosyl, and $0.1 \mathrm{M}$ 2-mercaptoethanol. After homogenization, the suspension was added to a solution containing an equal volume of $100 \mathrm{mM}$ Tris, pH 8.0, 10 mM EDTA, and 1\% SDS. The mixture was then extracted with chloroform-phenol and chloroform-isoamyl alcohol. The RNA was alcohol precipitated and the pellet dissolved in diethylpyrocarbonate-treated $\mathrm{H}_{2} \mathrm{O}$. Total RNA was separated by Northern analysis using formaldehyde, $1 \%$ agarose gels, transblotted onto nitrocellulose, baked, prehybridized, and hybridized with a ${ }^{32} \mathrm{P}-5$ ' end-labeled oligonucleotide probe. A 30-mer oligonucleotide probe was synthesized using the published cDNA sequence for human-derived MIP-1 $\alpha$ (34). The probe was complementary to nucleotides 105-134 and had the sequence 5'-GAG-AGC-CAT-GGT-GCA-GAG-GAG-GAC-AGCAAG-3'. Equivalent amounts of total RNA per gel were assessed by monitoring $28 \mathrm{~s}$ and $18 \mathrm{~s}$ rRNA.

Bioassay for chemotactic activity for PMNs or $m \phi s$. Normal human PMNs or $\mathbf{m} \phi \mathbf{s}$ were obtained from PB by Ficoll-Hypaque density gradient centrifugation. PMNs were separated from erythrocytes by hypotonic lysis and then suspended in HBSS with calcium and magnesium (GIBCO BRL, Bethesda, MD) at $2 \times 10^{6}$ cells $/ \mathrm{ml} . \mathrm{m} \phi \mathrm{s}$ were suspended in HBSS at $3 \times 10^{6}$ cells $/ \mathrm{ml}$. All cells were $>95 \%$ viable by trypan blue exclusion. Chemotaxis was performed as previously described $(3,16)$. In brief, $150 \mu$ l of SF that was diluted 1:1 with HBSS, $10^{-7}$ M FMLP for PMNs, or $10^{-8} \mathrm{M}$ FMLP for $m \phi s$ (SIGMA BRL), or HBSS alone was placed in duplicate bottom wells of a blind-well chemotaxis chamber. A 3- $\mu \mathrm{m}$-pore-size polyvinylpyrrolidone-free polycarbonate filter for PMN chemotaxis or a 5- $\mu \mathrm{m}$-pore-size filter for $\mathrm{m} \phi$ chemotaxis (Nucleopore Corp, Pleasanton, CA) was placed in the assembly and $250 \mu \mathrm{l}$ of cell suspension placed in each of the top wells. Chemotaxis chambers were incubated at $37^{\circ} \mathrm{C}$ in humidified $95 \%$ air/ $5 \% \mathrm{CO}_{2}$ for $1 \mathrm{~h}$ for PMN chemotaxis and $2 \mathrm{~h}$ for $\mathrm{m} \phi$ chemotaxis. The filters were removed, fixed in absolute methanol, and stained with $2 \%$ toluidine blue (Sigma Chemical Co.). PMNs or $\mathrm{m} \phi \mathrm{s}$ that had migrated through to the bottom of the filter were counted in 10 high power fields $(\times 1,000)$. Positive control $\mathrm{PB} \mathrm{m} \phi$ maximal recruitment in response to recombinant human ( $\mathrm{rh}$ ) MIP-1 $\alpha$ occurred at $100 \mathrm{ng} / \mathrm{ml} \mathrm{(28)}$. At 1:1,000 anti-MIP- $1 \alpha$ antiserum was capable of inhibiting $60-68 \%$ of the $\mathrm{m} \phi$ chemotactic activity induced by $1-100 \mathrm{ng} / \mathrm{ml} \mathrm{rhMIP}-1 \alpha(28)$. In neutralization studies, SF was incubated with a 1:1,000 dilution of either control rabbit preimmune serum or anti-MIP- $1 \alpha$ antiserum for $30 \mathrm{~min}$ at $37^{\circ} \mathrm{C}$ before the chemotactic assay.

Immunoperoxidase staining. Frozen ST sections $(4 \mu \mathrm{m})$ were cut, and immunoperoxidase was stained using an avidin-biotin technique (Vector Laboratories, Burlingame, CA) (35-37). Slides, air dried for 2-16 h, were fixed in cold acetone for $20 \mathrm{~min}$. All subsequent incubations were performed for $15 \mathrm{~min}$ at $37^{\circ} \mathrm{C}$ in a moist chamber. STs were pretreated with $50 \mu$ l diluted normal horse serum ( $135 \mu \mathrm{l}$ horse serum in $10 \mathrm{ml} 1 \%$ PBS-BSA, incubated with either rabbit anti-human MIP$1 \alpha$, preimmune rabbit serum, mAb Leu-M5, or control mAb, and washed twice. The slides were incubated with a 1:400 dilution of antirabbit biotinylated antibody in PBS-BSA, washed twice with PBS, incubated with avidin-conjugated horseradish peroxidase complex, and washed with PBS twice. Slides were then stained with diaminobenzidine tetrahydrochloride substrate for $5 \mathrm{~min}$ at room temperature, rinsed in tap water for 2 min, counterstained with Harris' hematoxylin, and dipped in saturated lithium carbonate solution for bluing. Serial tissue sections were examined to determine the percentage of each cell type expressing antigenic MIP- $1 \alpha$.

Cytospin preparations of isolated RA ST $\mathrm{m} \phi \mathrm{s}$ were made using $10^{5}$ cells per slide in a cytospin (Shandon I; Shandon, Swickley, PA). Slides were stained using immunohistochemistry as described above. 
Statistical analysis. Statistical analysis was performed using an analysis of variance (38). Correlations were performed using a Pearson correlation. $P$ values $<0.05$ were considered significant.

\section{Results}

Antigenic MIP-1 $\alpha$ is elevated in SF from $R A$ compared with $S F$ from $O A$ or other arthritis. MIP- $1 \alpha$ was measured by ELISA using samples obtained from 31 patients (Fig. 1). RA SFs contained the largest quantities of MIP- $\alpha \quad(29 \pm 8 \mathrm{ng} / \mathrm{ml}$ [mean $\pm \mathrm{SE}$ ]). RA SF levels of MIP- $1 \alpha$ were significantly greater than levels found in OA $(0.7 \pm 0.4 \mathrm{ng} / \mathrm{ml})$ or SFs from patients with other forms of arthritis $(2.8 \pm 1.7 \mathrm{ng} / \mathrm{ml} ; P$ $<0.05)$. Patients with other forms of arthritis included one with chronic myelogenous leukemia, one with mixed connective tissue disease, one with polymyositis, one with acute rheumatic fever, and two with Reiter's syndrome. In addition, RA SF MIP- $1 \alpha$ levels were greater than that found in RA or normal PB.

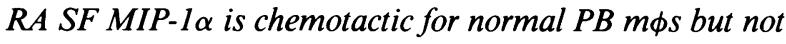
PMNs. To determine whether RA SF MIP- $1 \alpha$ was biologically active, we determined the relative contribution of SF MIP- $1 \alpha$ to chemotaxis for normal PB cellular constituents. In murine systems MIP- $1 \alpha$ is chemokinetic for PMNs in vitro as well as causes a rapid influx of PMNs when injected into the footpad of mice or intercisternally in rabbits (19). The effects of rhMIP- $1 \alpha$ on PMN chemotaxis are less clear, with some reports indicating that this cytokine is not chemotactic for PMNs $(39,40)$. We therefore determined the effect of neutralizing anti-MIP-1 $\alpha$ on RA SF chemotactic activity for normal human PB PMNs. While chemotactic activity for PMNs was present in the RA SFs, no diminution of the chemotactic response was found upon incubation of SFs with neutralizing anti-MIP-1 $\alpha$ (data not shown).

Recently, we have found that rhMIP- $1 \alpha$ in vitro is chemotactic for monocytes (28). We therefore examined the contribution of RA SF MIP- $1 \alpha$ to the chemotactic activity for normal PB $m \phi s$ found in these SFs. SFs were incubated with either nonimmune or anti-MIP- $1 \alpha$ antiserum (Table I). Chemotaxis was expressed as the mean cells per high power field $(\times 400)$. Incubation with either antibody did not alter the response to FMLP-induced chemotaxis. In contrast, incubation with antiMIP- $1 \alpha$ resulted in $31-49 \%$ (mean, $36 \pm 3 \%$ [SE]) suppression

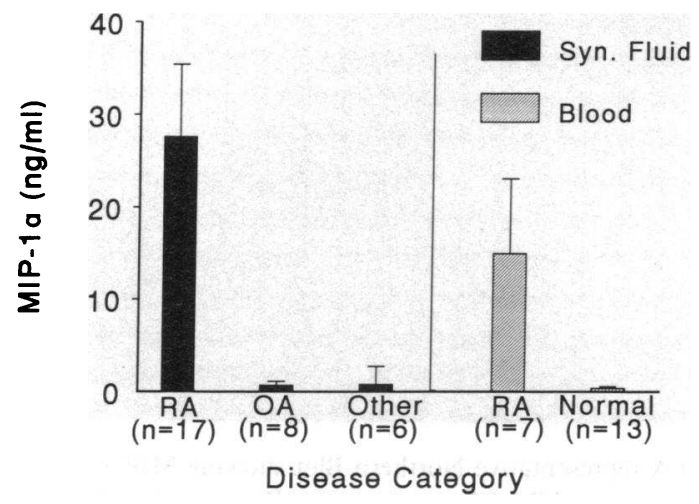

Figure 1. Antigenic MIP-1 $\alpha$ levels in SF from various arthritides as well as RA and normal PB. Results represent the mean \pm SE. Six replicate determinations per patient were performed. $(N)$ Number of patients examined.
Table I. Chemotaxis of Normal Human PB mos in Response to $R A$ SFs Incubated in the Presence and Absence of Anti-MIP-1 $\alpha$

\begin{tabular}{|c|c|c|c|c|}
\hline \multirow[b]{2}{*}{ Patient } & \multicolumn{2}{|c|}{$\begin{array}{l}\text { Mean cells/high power field } \\
\qquad(\times 400)\end{array}$} & \multirow[b]{2}{*}{$\begin{array}{c}\text { Percent } \\
\text { suppression* }\end{array}$} & \multirow[b]{2}{*}{ MIP-1 $\alpha^{t}$} \\
\hline & $\begin{array}{l}\text { Nonimmune } \\
\text { serum }\end{array}$ & Anti-MIP-1 $\alpha$ & & \\
\hline & & & & $n g / m l$ \\
\hline 1 & 161 & 82 & 49 & 2.5 \\
\hline 2 & 101 & 65 & 36 & 10.2 \\
\hline 3 & 98 & 62 & 38 & 16.8 \\
\hline 4 & 75 & 54 & 29 & 3.1 \\
\hline 5 & 80 & 56 & 31 & 3.2 \\
\hline 6 & 85 & 56 & 34 & 0.9 \\
\hline
\end{tabular}

RA SFs were assayed for their ability to induce chemotaxis of normal PB $m \phi s$. The results represent the analysis of 10 high power fields per sample. The ability of anti-MIP- $1 \alpha$ to neutralize chemotactic activity of $\mathrm{m} \phi \mathrm{s}$ was determined. Positive control migration in response to FMLP $\left(10^{-8} \mathrm{M}\right)$ was a mean of 129 cells per high power field. Negative control migration in response to HBSS was a mean of eight cells per high power field. ${ }^{*}$ For percent suppression in all patient samples assayed, $P<0.05$. ${ }^{\ddagger}$ MIP- $1 \alpha$ levels were determined by ELISA.

of chemotactic activity for $m \phi s$ of the SFs obtained from six RA patients.

$R A$ mononuclear cells produce MIP-1 $\alpha$ : augmentation with LPS or PHA stimulation. Since RA SFs contained MIP- $1 \alpha$, we determined the SF cell types responsible for production of this cytokine. To determine whether RA mononuclear cells produced MIP- $1 \alpha$, mononuclear cells were obtained from matched SF and PB from three patients. Cells $\left(2 \times 10^{6}\right.$ cells $/ \mathrm{ml}$ RPMI $+10 \%$ FCS) were cultured with or without LPS or PHA for $90 \mathrm{~h}$ and their supernatants assayed for antigenic MIP-1 $\alpha$ (Fig. 2). PB mononuclear cells released small quantities of MIP- $1 \alpha(2.8 \pm 0.7 \mathrm{ng} / \mathrm{ml}[\mathrm{SE}])$. MIP- $1 \alpha$ levels were augmented over threefold upon incubation of $\mathrm{PB}$ mononuclear cells with PHA, or LPS. Matching mononuclear cells obtained from SF

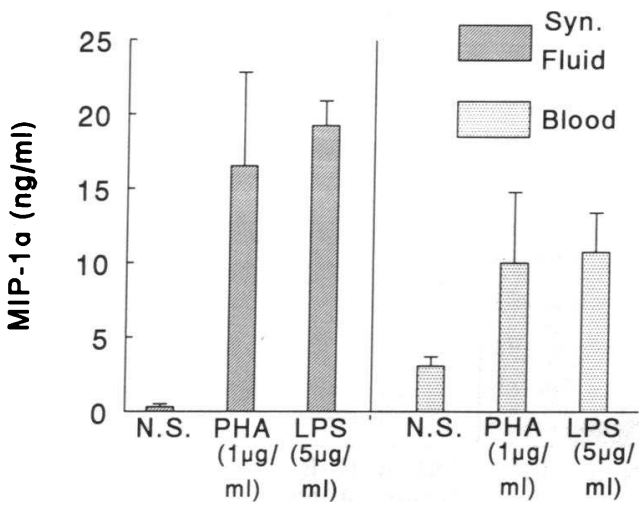

Figure 2. Mononuclear cells were isolated from matching SF and PB obtained from three RA patients. Cells $\left(2 \times 10^{6}\right.$ cells $/ \mathrm{ml}$ RPMI + $10 \%$ FCS) were cultured for $90 \mathrm{~h}$ in the presence or absence of LPS or PHA and supernatants were collected. Supernatants were assayed for antigenic MIP- $1 \alpha$ by ELISA. Results represent the mean \pm SE of six replicate determinations. (N.S.) Nonstimulated cells. 


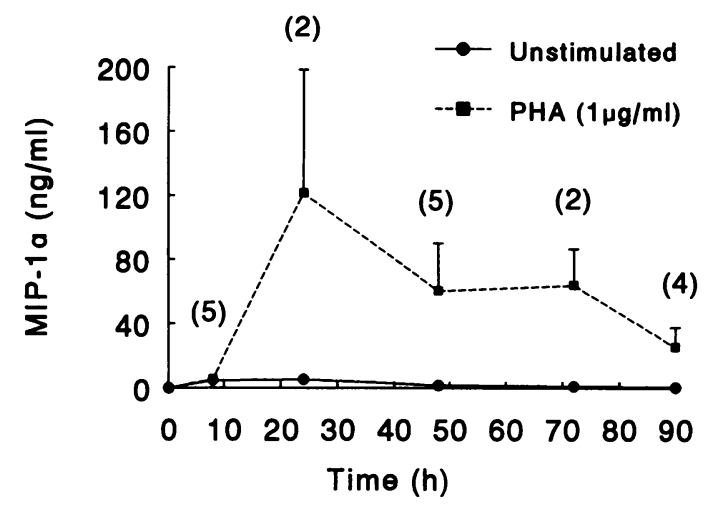

Figure 3. Time-dependent generation of SF mononuclear MIP-1 $\alpha$. Mononuclear cells were isolated from RA SFs. Cells $\left(2 \times 10^{6}\right.$ cells $/ \mathrm{ml}$ RPMI $+10 \%$ FCS) were cultured for various time periods in the presence or absence of PHA. Numbers in parentheses represent the number of patient samples available for a given time point. Results represent the mean $\pm \mathrm{SE}$ of six replicate determinations.

also produced small quantities of MIP- $1 \alpha(0.3 \pm 0.2 \mathrm{ng} / \mathrm{ml}$ [SE]), though these levels were not significantly different from those obtained from PB cells. Incubation of these mononuclear cells with PHA or LPS augmented MIP- $1 \alpha$ released $>50$-fold (Fig. 2).

To examine the time course of MIP- $1 \alpha$ secretion from RA $\mathrm{SF}$ mononuclear cells, cells were cultured in the presence or absence of PHA (Fig. 3). Nonstimulated cells released small quantities of MIP- $1 \alpha(4.0 \pm 2.1 \mathrm{ng} / \mathrm{ml}$ [SE] $)$. In contrast, PHAstimulated MIP- $1 \alpha$ production peaked by $24 \mathrm{~h}$ of cell culture, declining steadily over the next $72 \mathrm{~h}$ of culture.

$R A S T$ fibroblast production of MIP-1 $\alpha$ : augmentation upon LPS or TNF- $\alpha$ stimulation. We determined whether cells isolated from RA ST produced MIP- $1 \alpha$. Isolated RA fibroblasts from four RA patients were cultured in the presence or absence of IL- $1 \beta$, TNF- $\alpha$, or LPS, and supernatants were collected after $24 \mathrm{~h}$. While producing MIP- $1 \alpha$ without stimulation $(2.4 \pm 1.1 \mathrm{ng} / \mathrm{ml}[\mathrm{SE}])$, the production of fibroblast-derived MIP- $1 \alpha$ was augmented upon incubation of cells with LPS and to a lesser extent TNF- $\alpha$, but not IL-1 $\beta$ (Fig. 4).

$R A S T m \phi$ production of MIP-1 $\alpha$. Since we and others have shown previously that RA ST $m \phi s$ are important cells in the

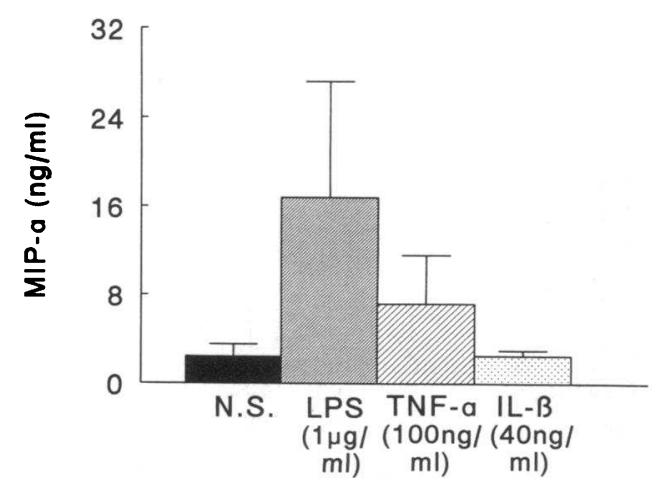

Figure 4. ST fibroblast MIP-1 $\alpha$ production by LPS or TNF- $\alpha$ stimulation. RA fibroblasts (3-4 × $10^{5}$ cells $/$ well) were cultured in serumfree RPMI for $24 \mathrm{~h}$. Results represent the mean \pm SE from four patient samples. Six replicates of each sample were assayed. (N.S.) Nonstimulated cells. production of cytokines in the RA joint, we assessed the levels of MIP- $1 \alpha$ mRNA from isolated RA $m \phi s$. RA $m \phi s$ isolated in this fashion expressed constitutive steady-state MIP- $1 \alpha$ mRNA (Fig. 5). This compares to virtually absent steady state MIP-1 $\alpha$ mRNA levels obtained from resting normal human PB $\mathrm{m} \phi \mathrm{s}$ (data not shown) (27). Cytospin preparations of these same cells were analyzed for antigenic MIP- $1 \alpha$ by immunohistochemistry. These isolated $m \phi s$ were found to be positive for the expression of MIP- $1 \alpha$ antigen.
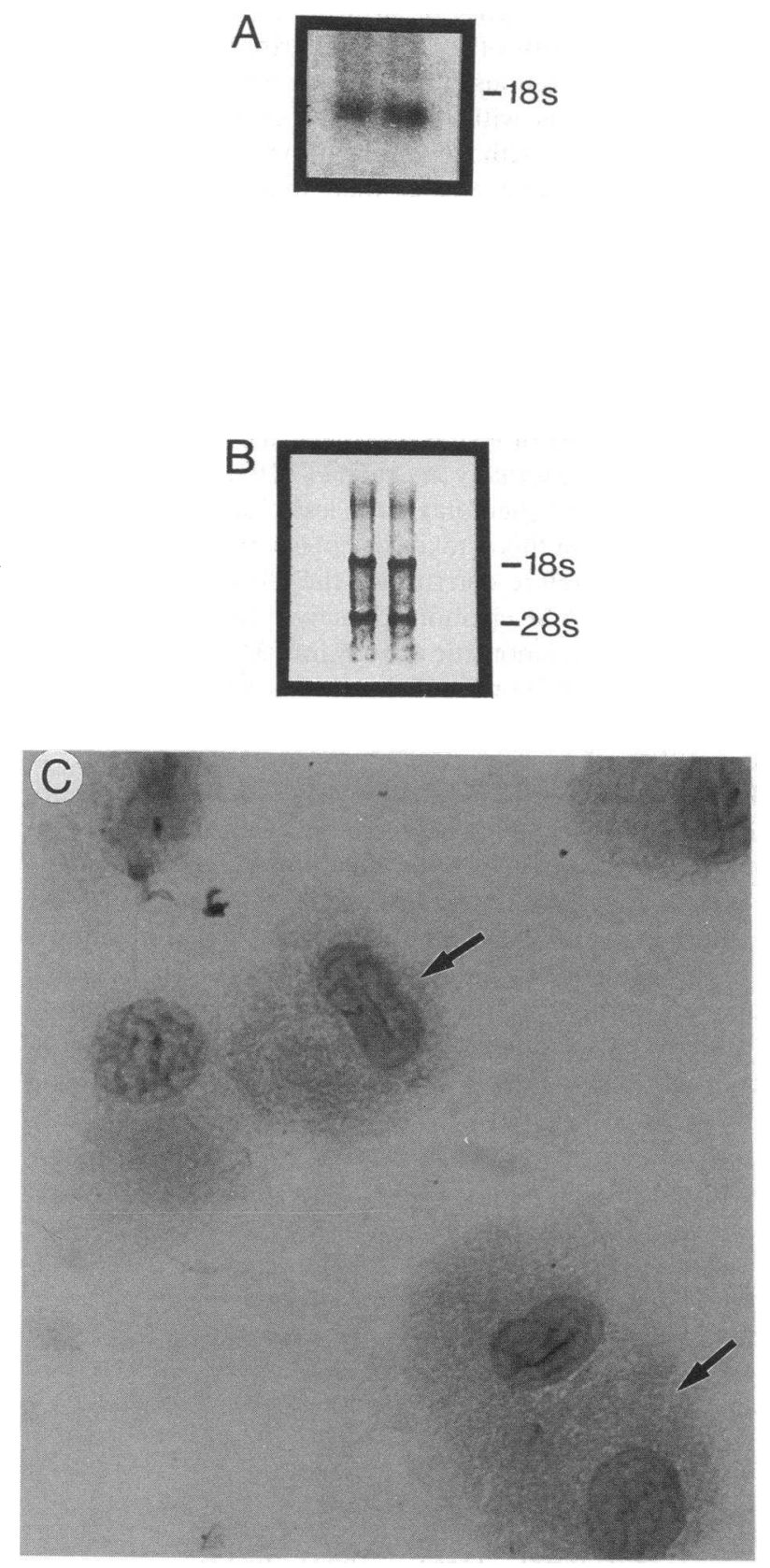

Figure 5. (A) A representative Northern Blot showing MIP-1 $\alpha$ gene expression from isolated RA ST $m \phi s$ from two RA patients. $(B) 18 S$ and $28 \mathrm{~S}$ rRNA demonstrating equivalent loading of total RNA in $A$. (C) Immunoperoxidase stained cytocentrifuge preparation of freshly isolated RA ST $\mathbf{m} \phi \mathbf{s}$ showing MIP- $1 \alpha$ antigen expression (arrows) ( $\times 870)$. 

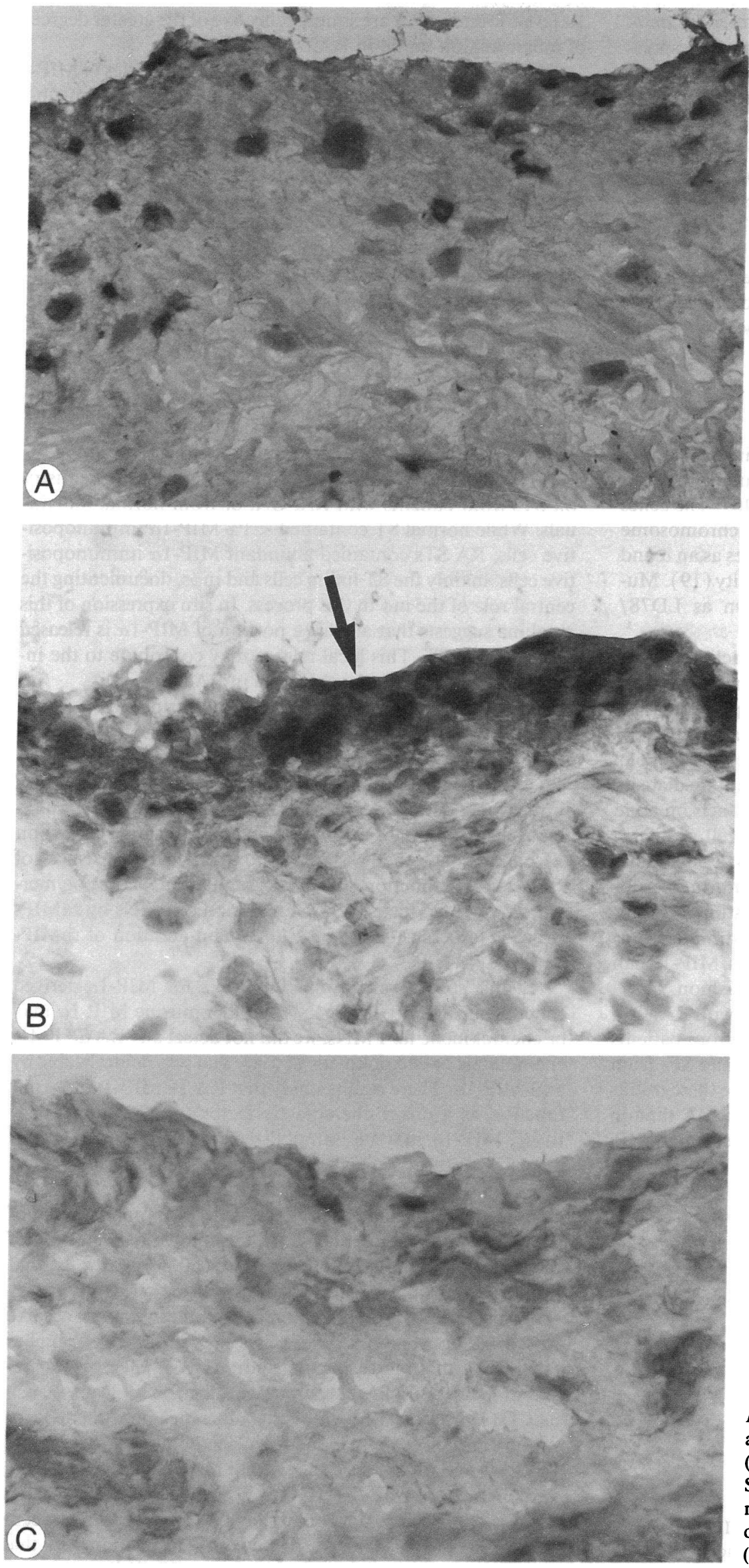

Figure 6. Immunoperoxidase reactivity of anti-MIP- $1 \alpha$ with frozen human STs $(\times 422)$. $(A)$ Lack of MIP- $\alpha$-reactive cells in a normal ST. ( $B$ ) Intense lining layer (arrow) MIP-1 $\alpha$ reactivity in an RA ST. $(C)$ Lack of reactivity of RA ST with treated with nonimmune serum (control). 
$R A S T$ lining cells and $m \phi s$ are immunopositive for antigenic MIP-1 $\alpha$. To determine which cells in the STs were responsible for MIP- $1 \alpha$ production in vivo, we performed immunohistochemistry on frozen ST samples from 9 patients with RA, 10 patients with OA, and 4 normal individuals. RA ST $\mathrm{m} \phi \mathrm{s}$ and lining cells were MIP- $1 \alpha$ immunopositive (Fig. 6). While $35 \pm 10 \%$ (SE) of RA ST lining cells expressed antigenic MIP$1 \alpha$, significantly fewer normal lining cells were MIP- $1 \alpha$ immunopositive $(0.3 \pm 0.3$ [SE]; $P<0.05)$ (Fig. 7). Similarly, while $24 \pm 6 \%$ (SE) of RA ST $m \phi$ s were MIP- $1 \alpha$ immunopositive, only $1 \pm 0.7 \%$ (SE) of normal ST $\mathrm{m} \phi$ s were MIP- $1 \alpha$ immunopositive $(P<0.05)$ (Fig. 7). OA lining cells and $\mathrm{m} \phi \mathrm{s}$ were immunopositive for MIP-1 $\alpha$, however, fewer cells were positive than were found in RA STs.

\section{Discussion}

MIP- $1 \alpha$ is a recently described cytokine belonging to the C-C chemokine supergene family $(39,41)$. This family includes ACT-2, I-309, RANTES, TCA-3, and MCP-1 (40). The genes encoding this supergene family reside on human chromosome 17 (40). The murine MIP- $1 \alpha$ homologue migrates as an $\alpha$ and $\beta$ doublet with $60 \%$ peptide and $57 \%$ cDNA identity (19). Murine MIP- $1 \alpha$ and human MIP- $1 \alpha$ (also known as LD78/ pAt464) have $75 \%$ amino acid homology (19).

MIP- $1 \alpha$ has a variety of proinflammatory activities that suggest its possible importance in chronic inflammatory diseases like RA. Murine MIP- $1 \alpha$ is an endogenous pyrogen when given intravenously to rabbits or into the hypothalamic preoptic area of the rat $(42,43)$. However, unlike other endogenous pyrogens, such as IL- 1 or TNF- $\alpha$, MIP- $1 \alpha$ does not mediate its pyrogenic effect via prostaglandins (42). MIP-1 $\alpha$ acts on bone marrow colony-forming units to regulate stem cell proliferation $(44,45)$. MIP- $1 \alpha$ has recently been found to be chemotactic for T lymphocytes (26). MIP-1 $\alpha$ activates murine peritoneal $\mathrm{m} \phi \mathrm{s}$ to become cytotoxic for tumors, and stimulates $\mathrm{m} \phi$ proliferation. Murine MIP- $1 \alpha$, but not MIP- $1 \beta$, stimulates $\mathrm{m} \phi$ secretion of IL- $1 \alpha$, TNF- $\alpha$, or IL-6 $(46,47)$. Thus, MIP- $1 \alpha$ can act directly on its cell of origin in an autocrine fashion.

In this study we examined SFs from patients with RA, OA, and other forms of arthritis. We found that SFs from patients with RA contained significantly more MIP- $1 \alpha$ than SFs from patients with OA or other forms of arthritis. While these results may imply a more important role for MIP- $1 \alpha$ in RA than in other forms of arthritis, it is also possible that the higher MIP-

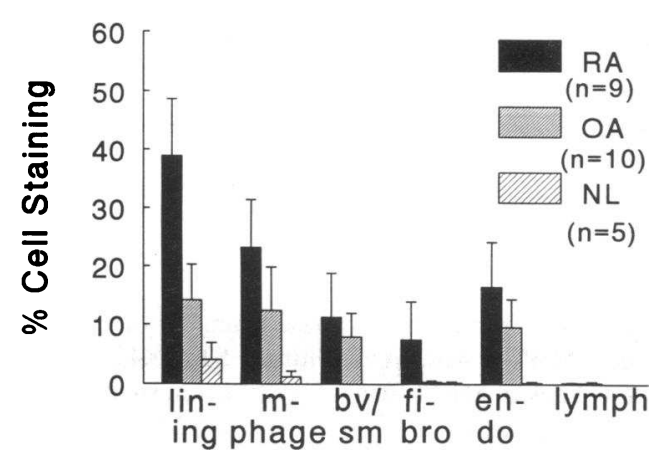

Figure 7. Immunohistochemical demonstration of MIP-1 $\alpha$ expression in STs. (mphage) Macrophage; ( $b v / s m)$ vascular smooth muscle; (fibro) fibroblast; (endo) endothelial cell; (lymph) lymphocyte.
$1 \alpha$ levels found in RA are simply reflective of the greater degree of inflammation found in RA.

Having found that RA SF contains large quantities of MIP$1 \alpha$, we determined which specific cell types in the SF contributed to production of this cytokine. RA SF and PB mononuclear cells produced small amounts of MIP- $1 \alpha$ constituitively. To determine the regulation of MIP- $1 \alpha$ production, we incubated SF cells with PHA or LPS. Mononuclear cell MIP-1 $\alpha$ production was augmented by LPS or PHA stimulation.

We next determined whether cells in RA STs produced antigenic MIP- $1 \alpha$. RA ST fibroblasts produced MIP- $1 \alpha$, particularly in response to TNF- $\alpha$ or LPS. Hence, RA ST fibroblasts respond to some of the same stimuli that induce production of IL-8 and MCP- 1 in the inflamed joint $(3,16)$. RA ST $m \phi s$ expressed both constitutive MIP- $1 \alpha$ mRNA and protein. Thus, MIP- $1 \alpha$, like MCP-1 and IL-8, is constitutively produced by ST $\mathbf{m} \phi \mathbf{s}$ in the context of chronic synovial inflammation.

To determine the contribution of other cell types to MIP$1 \alpha$ production in vivo, we performed immunohistochemistry on STs from patients with RA, OA, or from normal individuals. While normal ST contained $<1 \%$ MIP- $1 \alpha$ immunopositive cells, RA STs contained abundant MIP- $1 \alpha$ immunopositive cells, mainly the ST lining cells and $m \phi s$, documenting the central role of the $m \phi$ in this process. In situ expression of this cytokine suggests that at least a portion of MIP-1 $\alpha$ is released from the RA ST. This local release may contribute to the increased serum MIP- $1 \alpha$ levels found in RA.

One of the main reported actions of murine MIP- $1 \alpha$ is to attract PMNs (48). Murine MIP-1 $\alpha$, when injected intradermally in mice, elicits a potent PMN response (48). McColl et al. (40) have recently shown that rhMIP-1 $\alpha$ stimulates PMN intracellular calcium accumulation accompanied by a simultaneous change in right-angle light scatter, indicating induction of shape change that was not accompanied by measures of PMN effector function such as degranulation, actin polymerization, or chemotaxis (40). Stimulation of PMNs by rhMIP$1 \alpha$ leads to desensitization to subsequent addition of rhMIP$1 \alpha(40)$.

In this study, we examined RA SFs for MIP- $1 \alpha$-derived chemotactic activity for PMNs. Though murine MIP- $1 \alpha$ may be chemokinetic for PMNs, we did not detect any RA SF PMN chemotactic or chemokinetic activity that was neutralizable by anti-MIP-1 $\alpha$. These results imply that RA SF MIP- $1 \alpha$ does not function as a direct chemotactic factor for PMNs. Alternatively, MIP- $1 \alpha$ may be immobilized to ST endothelium and exert a chemotactic effect for PMNs in this fashion, as has been proposed for the related chemokine IL-8 (49). Rot (49) showed that IL-8 binds selectively to the luminal surface of small blood vessel endothelium, the site of transmigration of recruited cells. Similarly, Tanaka et al. $(50,51)$ proposed that proteoglycans on the luminal surface of endothelium are responsible for the immobilization of proadhesive cytokines like MIP- $1 \beta$. Finally, it is possible, as has been suggested by Hughes et al. (52), that increasing concentrations of chemotaxins result in increases in PMN cell surface adhesion molecules, such as $\mathrm{CD} 1 \mathrm{lb} / \mathrm{CD} 18$, with resultant adherence-dependent locomotion and subsequent increases in chemokine concentration. Since we and others have shown that the RA joints are replete with cells expressing CD11b, it is possible that such a mechanism is operative in the context of $\operatorname{RA}(53,54)$. More recent studies by Wang et al. (55), however, have indicated that rhMIP- $1 \alpha$ is not chemotactic for human PB PMNs. Thus, in 
accord with the studies reported by Wang et al. (55) for human PB PMNs, it appears that RA SF MIP- $1 \alpha$ is not a direct chemotactic factor for PMNs.

$\mathrm{m} \phi \mathrm{s}$ are key effector cells in the pathogenesis of RA. $\mathrm{m} \phi \mathrm{s}$ function as antigen-presenting cells as well as potent secretory cells, liberating cytokines such as IL-1, TNF- $\alpha$, IL-8, and MCP$1(3-11,13,14,16-18,56-58)$. Additionally, they release arachidonic acid metabolites, oxygen free radicals, and proteases such as collagenase and stromolysin (56). These cells are also important in the neovascularization, which accompanies the growth and proliferation of the hypertrophic ST $(32,33,58)$. The mechanisms by which these important cells enter the synovial tissue have as yet not been fully defined.

One of the prominent effects of human MIP- $1 \alpha$ appears to be on the $\mathrm{m} \phi$. The effects of human MIP-1 $\alpha$ on human mononuclear phagocytes are beginning to be elucidated. We and others have recently shown that human MIP- $1 \alpha$ is a potent chemotaxin for human $m \phi s$, being chemotactic but not chemokinetic for these cells $(28,55)$. Other $\mathrm{m} \phi$ chemotactic cytokines present in the RA joint include transforming growth factor- $\beta$, platelet-derived growth factor, GM-CSF, lymphocytederived chemotactic factor, and MCP-1 (3). Indeed, we found that anti-MIP- $1 \alpha$ resulted in suppression of over one-third of the chemotactic activity for $m \phi s$ found in RA SFs. Thus, MIP$1 \alpha$ may function in conjunction with these other $\mathrm{m} \phi$ chemotactic factors to recruit $m \phi s$ into the RA joint.

In summary, in this study we have shown that RA SFs contain significantly more MIP- $1 \alpha$ than SFs from OA or other forms of arthritis. Mononuclear cells found in RA SFs are capable of producing MIP- $1 \alpha$, and both LPS and PHA are potent stimuli for their MIP-1 $\alpha$ production. Likewise, cells from the RA ST were found to produce MIP- $1 \alpha$. RA ST fibroblasts produced MIP- $1 \alpha$, particularly in response to LPS or TNF- $\alpha$ stimulation. RA ST $\mathrm{m} \phi \mathrm{s}$ constituitively produced MIP- $1 \alpha$, and along with ST lining cells, were the main MIP- $1 \alpha$ immunopositive cells found in the ST. One of the main biological functions of MIP- $1 \alpha$ in the RA joint appears to be the direct recruitment of $\mathrm{m} \phi \mathrm{s}$, with MIP-1 $\alpha$ accounting for over one-third of the chemotactic activity for $\mathrm{m} \phi \mathrm{s}$ found in RA SFs. Hence, MIP- $1 \alpha$ may be one of the major cytokines contributing to the chemoattraction and retention of RA $m \phi s$ in the inflamed joint.

\section{Acknowledgments}

We thank our colleagues, Drs. S. D. Stulberg, C. Schwartz, J. Galante, N. Rana, B. Briggs, G. Rayan, and J. Lessard, for supplying the STs. We would also like to thank Drs. Herbert Rubinstein and Frank Schmid for helpful discussions. We wish to acknowledge the invaluable help of Dr. James Sinacore in performing statistical analysis of the data. We thank Ms. Corinne Washington for expert secretarial assistance.

This work was supported by National Institutes of Health grants AR-30692 (R. M. Pope), AR-41492 (A. E. Koch), HL-02401 and HL-50057 (R. M. Strieter), HL-31693 (S. L. Kunkel), and SCOR grant IP50 HL-46487 (R. M. Strieter and S. L. Kunkel); The Dr. Ralph and Marion Falk Challenge Prize of the Illinois Chapter Arthritis Foundation (A. E. Koch); and funds from the Veteran's Administration Research Service (A. E. Koch and R. M. Pope). R. M. Strieter is an RJR-Nabisco Research Scholar.

\section{References}

1. Harris, E. D. 1988. Pathogenesis of rheumatoid arthritis: a disorder associated with dysfunctional immunoregulation. In Inflammation: Basic Principles and Clinical Correlates. J. I. Gallin, I. M. Goldstein, and R. Snyderman, editors. Raven Press Ltd., New York. 751-773.

2. Firestein, G. S. 1991. The immunopathogenesis of rheumatoid arthritis Curr. Opin. Rheumatol. 3:398-406.

3. Koch, A. E., S. L. Kunkel, J. C. Burrows, H. L. Evanoff, G. K. Haines, R. M. Pope, and R. M. Strieter. 1991. Synovial tissue macrophage as a source of the chemotactic cytokine IL-8. J. Immunol. 147:2187-2195.

4. Wood, D. D., E. J. Ihrie, and D. Hamerman. 1985. Release of interleukin-1 from human synovial tissue in vitro. Arthritis Rheum. 28:853-862.

5. Miyasaka, N., K. Sato, M. Goto, M. Sasano, M. Natsuyama, K. Inoue, and K. Nishioka. 1988. Augmented interleukin-1 production and HLA-DR expression in the synovium of rheumatoid arthritis patients. Possible involvement in joint destruction. Arthritis Rheum. 31:480-486.

6. Yocum, D. E., L. Esperanza, S. Dubry, J. B. Benjamin, R. Volz, and P. Scuderi. 1989. Characteristics of tumor necrosis factor production in rheumatoid arthritis. Cell. Immunol. 122:131-145.

7. Husby, G., and R. C. Williams, Jr. 1988. Synovial localization of tumor necrosis factor in patients with rheumatoid arthritis. J. Autoimmun. 1:363-371.

8. Lipsky, P. E., L. S. Davis, J. J. Cush, and N. Oppenheimer-Marks. 1989. The role of cytokines in the pathogenesis of rheumatoid arthritis. Springer Semin. Immunopathol. 11:123-162.

9. Arend, W. P., and J. M. Dayer. 1990. Cytokines and cytokine inhibitors or antagonists in rheumatoid arthritis. Arthritis Rheum. 33:305-315.

10. Koch, A. E., S. L. Kunkel, S. W. Chensue, G. K. Haines, and R. M. Strieter. 1992. Constitutive expression of interleukin-1 and interleukin-1 receptor antagonist by human synovial tissue macrophages. Clin. Immunol. Immunopathol. 65:23-29.

11. Lotz, M., T. Moats, and Peter M. Villiger. 1992. Leukemia inhibitory factor is expressed in cartilage and synovium and can contribute to the pathogenesis of arthritis. J. Clin. Invest. 90:888-896.

12. Dayer, J.-M., B. deRochemonteix, B. Burrus, S. Demczuk, and C. A. Dinarello. 1986. Human recombinant interleukin 1 stimulates collagenase and prostaglandin $\mathrm{E}_{2}$ production by human synovial cells. J. Clin. Invest. 77:645648 .

13. Dayer, J.-M., B. Beutler, and A. Cerami. 1985. Cachectin/tumor necrosis factor exerts endocrine, paracrine, and autocrine control of inflammatory responses. J. Exp. Med. 162:2163-2168.

14. Firestein, G. S., J. M. Alvaro-Garcia, and R. Maki. 1990. Quantitative analysis of cytokine gene expression in rheumatoid arthritis. J. Immunol. 144:3347-3353.

15. Firestein, G. S., A. E. Berger, D. E. Tracey, J. G. Chosay, D. L. Chapman, M. M. Paine, C. Yu, and N. J. Zvaifler. 1992. IL-1 receptor antagonist protein production and gene expression in rheumatoid arthritis and osteoarthritis synovium. J. Immunol. 149:1054-1062.

16. Koch, A. E., S. L. Kunkel, L. A. Harlow, B. Johnson, H. L. Evanoff, G. K. Haines, M. D. Burdick, R. M. Pope, and R. M. Strieter. 1992. Enhanced production of monocyte chemoattractant protein-1 in rheumatoid arthritis. J. Clin. Invest. 90:772-779.

17. Seltz, M., B. DeWald, N. Gerber, and M. Baggiolini. 1991. Enhanced production of neutrophil activating peptide-1 / interleukin-8 in rheumatoid arthritis. J. Clin. Invest. 87:463.

18. Brennan, F. M., C. O. C. Zachariae, D. Chantry, C. G. Larsen, M. Turner, R. N. Maini, K. Matsushima, and M. Feldmann. 1990. Detection of interleukin 8 biological activity in synovial fluids from patients with rheumatoid arthritis and production of interleukin 8 mRNA by isolated synovial cells. Eur. J. Immunol. 20:2141-2144.

19. Wolpe, S. D., and A. Cerami. 1989. Macrophage inflammatory proteins 1 and 2: members of a novel superfamily of cytokines. FASEB (Fed. Am. Soc. Exp. Biol.) J. 3:2565-2573.

20. Davatelis, G., P. Tekamp-Olson, S. D. Wolpe, K. Hermsen, C. Luedke, C. Gallegos, D. Coit, J. Merryweather, and A. Cerami. 1988. Cloning and characterization of a cDNA for murine macrophage inflammatory protein (MIP), a novel monokine with inflammatory and chemokinetic properties. J. Exp. Med. 19391944.

21. Widmer, U., Z. Yang, S. Van Deventer, K. R. Mannogue, B. Sherry, and A. Cerami. 1991. Genomic structure of murine macrophage inflammatory protein- $1 \alpha$ and conservation of potential regulatory sequences with a human homo$\log$, LD78. J. Immunol. 146:4031-4040.

22. Yamamura, Y., T. Hattori, K. Obaru, K. Sakai, N. Asou, K. Takatsuki, Y. Ohmoto, H. Nomiyama, and K. Shimada. 1989. Synthesis of a novel cytokine and its gene (LD78) expressions in hematopoietic fresh tumor cells and cell lines. J. Clin. Invest. 84:1707-1712.

23. Blum, S., R. E. Forsdyke, and D. R. Forsdyke. 1990. Three human homologs of a murine gene encoding an inhibitor of stem cell proliferation. DNA Cell Biol. 9:589-602.

24. Kasama, T., R. M. Strieter, T. J. Standiford, M. D. Burdick, and S. L. Kunkel. 1994. Expression and regulation of human neutrophil-derived macrophage inflammatory protein-1 $\alpha($ MIP-1 $\alpha)$. J. Exp. Med. 178:63-72.

25. Abruzzo, L. V., R. M. Strieter, T. J. Standiford, and S. L. Kunkel. 1990. MIP-1 $\alpha$ gene expression in vivo and in vitro. In Molecular and Cellular Biology of 
Cytokines. J. J. Oppenheim, M. C. Powanda, M. J. Kluger, and C. A. Dinarello, editors. Wiley-Liss, Inc., New York. 403-408.

26. Taub, D. D., K. Conlon, A. R. Lloyd, J. J. Oppenheim, and D. J. Kelvin 1993. Preferential migration of activated $\mathrm{CD}^{+}$and $\mathrm{CD} 8^{+} \mathrm{T}$ cells in response to MIP- $1 \alpha$ and MIP-1 1 . Science (Wash. DC). 260:355-358.

27. Standiford, T. J., S. L. Kunkel, J. M. Liebler, M. D. Burdick, A. R. Gilbert and R. M. Strieter. 1994. The gene expression of MIP-1 $\alpha$ from human blood monocytes and alveolar macrophages is inhibited by IL-4. Am. J. Respir. Cell Mol. Biol. 9:192-198.

28. Standiford, T. J., M. W. Rolfe, S. L. Kunkel, J. P. Lynch III, M. D. Burdick, A. R. Gilbert, M. B. Orringer, R. I. Whyte, and R. M. Strieter. 1994. Macrophage inflammatory protein-1 alpha expression in interstitial lung disease. J. Immunol. 151:2852-2863.

29. Arnett, F. C., S. M. Edworthy, D. A. Bloch, D. J. McShane, J. F. Fries, N. S. Cooper, L. A. Healey, S. R. Kaplan, M. H. Liang, H. S. Luthra, et al. 1988. The American Rheumatism Association 1987 revised criteria for the classification of rheumatoid arthritis. Arthritis Rheum. 31:315-324.

30. Altman, R., E. Asch, D. Bloch, G. Bole, D. Borenstein, K. Brandt, W. Christy, T. D. Cooke, R. Greenwald, and M. Hochberg. 1986. Development of criteria for the classification and reporting of osteoarthritis: classification of osteoarthritis of the knee. Arthritis Rheum. 29:1039-1049.

31. Pope, R. M., A. Landay, R. L. Modlin, J. Lessard, and A. E. Koch. 1991. $\gamma / \delta \mathrm{T}$ cell receptor positive $\mathrm{T}$ cells in the inflammatory joint: lack of association with response to soluble antigens. Cell. Immunol. 137:127-138.

32. Koch, A. E., P. J. Polverini, and S. J. Leibovich. 1986. Stimulation of neovascularization by human rheumatoid synovial tissue macrophages. Arthritis Rheum. 29:471-479.

33. Koch, A. E., S. J. Leibovich, and P. J. Polverini. 1988. Functional heterogeneity of human rheumatoid synovial tissue macrophages. J. Rheumatol. 15:1058-1063.

34. Zipfel, P. F., J. Balke, S. G. Irving, K. Kelly, and U. Siebenlist. 1989. Mitogenic activation of human $T$ cells induces two closely related genes which share structural similarities with a new family of secreted factors. J. Immunol. 142:1582-1590.

35. Koch, A. E., G. K. Haines, R. Rizzo, J. A. Radosevich, R. M. Pope, P. G. Robinson, and W. H. Pearce. 1990. Human abdominal aortic aneurysms: immunophenotypic analysis suggesting an immune-mediated response. Am. J. Pathol. 137:1199-1213.

36. Koch, A. E., J. A. Radosevich, P. G. Robinson, and R. M. Pope. 1990. Distribution of CD45RA ${ }^{+}$and CD45RO ${ }^{+} \mathrm{T}$ lymphocyte subsets in rheumatoid arthritis synovial tissue. J. Clin. Immunol. 10:192-199.

37. Koch, A. E., J. C. Burrows, R. M. Marder, P. Domer, and S. J. Leibovich. 1990. Reactivity of human tissues with monoclonal antibodies to myeloid activation and differentiation antigens. Pathobiology. 58:241-248.

38. Winer, B. J. 1971. Statistical Principles in Experimental Design. McGraw Hill Inc., New York. 000 pp.

39. Schall, T. J. 1991. Biology of the RANTES/SIS cytokine family. Cytokine. 3:165-183.

40. McColl, S. R., M. Hachicha, S. Levasseur, K. Neote, and T. J. Schall. 1993. Uncoupling of early signal transduction events from effector function in human peripheral blood neutrophils in response to recombinant macrophage inflammatory proteins- $1 \alpha$ and $-1 \beta$. J. Immunol. 150:4550-4560.

41. Oppenheim, J. J., C. O. C. Zachariae, and N. Mukaida. 1991. Properties of the novel proinflammatory supergene "intercrine" cytokine family. Annu. Rev. Immunol. 9:617-648.
42. Davatelis, G., S. D. Wolpe, B. Sherry, J.-M. Dayer, R. Chicheportiche, and A. Cerami. 1989. Macrophage inflammatory protein-1: a prostaglandin-independent endogenous pyrogen. Science (Wash. DC). 243:1066-1068.

43. Minano, F. J., M. Sancibrian, M. Vizcaino, X. Paex, G. Davatelis, T. Fahey, B. Sherry, A. Cerami, and R. D. Myers. 1990. Macrophage inflammatory protein-1: unique action on the hypothalamus to evoke fever. Brain Res. Bull. 24:849-852.

44. Broxmeyer, H. E., B. Sherry, S. Cooper, F. W. Ruscetti, D. E. Williams, P. Arosio, B. S. Kwon, and A. Cerami. 1991. Macrophage inflammatory protein (MIP)-1 $\beta$ abrogates the capacity of MIP-1 $\alpha$ to suppress myeloid progenitor cell growth. J. Immunol. 147:2586-2594.

45. Graham, G. J., E. G. Wright, R. Hewick, S. D. Wolpe, N. M. Wilke, D. Donaldson, S. Lorimore, and I. B. Pragnell. 1990. Identification and characterization of an inhibitor of haemopoietic stem cell proliferation. Nature (Lond.). 344:442-444.

46. Fahey III, T. J., K. J. Tracey, P. Tekamp-Olson, L. S. Cousens, W. G. Jones, T. Shires, A. Cerami, and B. Sherry. 1992. Macrophage inflammatory protein 1 modulates macrophage function. J. Immunol. 148:2764-2769.

47. Martin, C. A., and M. E. Dorf. 1991. Differential regulation of interleukin-6, macrophage inflammatory protein-1, and JE/MCP-1 cytokine expression in macrophage cell lines. Cell. Immunol. 135:245-258.

48. Wolpe, S. D., G. Davatelis, B. Sherry, B. Beutler, D. G. Hesse, H. T. Nguyen, L. L. Moldawer, C. F. Nathan, S. F. Lowry, and A. Cerami. 1988 Macrophages secrete a novel heparin-binding protein with inflammatory and neutrophil chemokinetic properties. J. Exp. Med. 167:570-581.

49. Rot, A. 1992. Endothelial cell binding of NAP-1/IL-8: role in neutrophil emigration. Immunol. Today. 13:291-294.

50. Tanaka, Y., D. H. Adams, and S. Shaw. 1993. Proteoglycans on endothelial cells present adhesion-inducing cytokines to leukocytes. Immunol. Today. 14:111-115.

51. Tanaka, Y., D. H. Adams, S. Hubscher, H. Hirano, U. Siebenlist, and S. Shaw. 1993. T cell adhesion induced by proteoglycan-immobilized cytokine MIP-1 $\beta$. Nature (Lond.). 361:79-82.

52. Hughes, B. J., J. C. Hollers, E. Crockett-Torabi, and C. W. Smith. 1992. Recruitment of CD1 1b/CD18 to the neutrophil surface and adherence-dependent cell locomotion. J. Clin. Invest. 90:1687-1696.

53. Koch, A. E., J. C. Burrows, G. K. Haines, T. M. Carlos, J. Harlan, and S. J. Leibovich. 1991. Immunolocalization of leukocyte and endothelial adhesion molecules in human rheumatoid and osteoarthritic synovial tissues. Lab. Invest 64:113-320.

54. Johnson, B. J., G. K. Haines, L. A. Harlow, and A. E. Koch. 1993. Adhesion molecule expression in human synovial tissue. Arthritis Rheum. 36:137146.

55. Wang, J. M., B. Sherry, M. J. Fivish, D. J. Kelvin, and J. J. Oppenheim. 1993. Human recombinant macrophage inflammatory protein- $1 \alpha$ and monocyte chemotactic and activating factor utilize common and unique receptors on human monocytes. J. Immunol. 150:3022-3029.

56. Villiger, P. M., R. Terkeltaub, and M. Lotz. 1992. Production of monocyte chemoattractant protein-1 by inflamed synovial tissue and cultured synoviocytes. J. Immunol. 149:722-727.

57. Peichl, P., M. Ceska, F. Effenberger, G. Haberhauer, H. Broell, and I. J. D. Lindley. 1991. Presence of NAP-1/IL-8 in synovial fluids indicates a possible pathogenic role in rheumatoid arthritis. Scand. J. Immunol. 34:333-339.

58. Koch, A. E., P. J. Polverini, S. L. Kunkel, L. A. Harlow, L. A. DiPietro, V. M. Elner, S. G. Elner, and R. M. Strieter. 1992. Interleukin-8 as a macrophagederived mediator of angiogenesis. Science (Wash. DC). 25:1798-1801. 